\title{
The feeding value of green and ensiled São Jorge natural pasture
}

\author{
AES Borba 1, CFM Vouzela 1, Anabela FRS Borba ${ }^{2}$ \\ 1 Departamento de Ciências Agrárias, Universidade dos Açores, 9700 Angra do Heroismo, Açores ; \\ 2Serviço de Desenvolvimento Agrário da Terceira, SRAP, 9700 Angra do Heroismo, Açores, Portugal
}

São Jorge is an Azorean Island where quality cheese is the main agricultural product. Milk production depends on grazing natural pasture. The Island climate is characterised by rainy and windy winters with low grass production, therefore, silage is required for maintenance of animals and production of milk. The use of big bale silage was recently introduced into the island.

This paper presents the results of a study of the feeding value of São Jorge pastures in green and in big bale silage.

The forage sample was dried at $65^{\circ} \mathrm{C}$ and ground to a particle size of $1 \mathrm{~mm}$. The following parameters were measured : dry matter (DM), ash, crude protein (CP), (AOAC, 1975, Official Methods of Analysis, USA), NDF, ADF, and ADL (Goering and Van Soest, 1970, USDA Agric Handbook $n^{\circ} 379$, USA). In silage the following was quantified : $\mathrm{pH}$, $\mathrm{N}-\mathrm{NH}_{3} / \%$ NT (Conway, 1957, Microdiffusion Analysis and Volumetric Error, Crosby Lockwood, UK).

Four adult Romney-Marsh male sheep per treatment were used for the in vivo DM digestibility (DMD) determinations.

The digestibility trials lasted 21 days; there was a 14 day adaptation period and a 7 day collection period. The animals were fed ad libitum twice a day, at 9:00 $\mathrm{h}$ and at 17:00 h. The quantity of food offered was the same as the previous days consumption plus $10 \%$.

These trials indicated that the natural pasture had low crude protein and low dry matter digestibility and was poorly ingested.

Based on the $\mathrm{pH}, \mathrm{N}-\mathrm{NH}_{3}$ values and the classification used by Vanbelle et al (1981, L'ensilage un problème d'actualité, Louvain-laNeuve, Belgique), the silage was very good (pH 3.8; $\mathrm{N}-\mathrm{NH}_{3} / \%$ NT 7.9).

We observed a decrease in DMD and DM intake (DMI, $\mathrm{g} / \mathrm{kgW}^{0.75}$ ) between green and ensiled forage, but this decrease was not significant $(P<0.05)$.

We can conclude that the big bale silage process did not have a significative influence in the nutritive value of São Jorge natural pastures.

\begin{tabular}{|c|c|c|c|c|c|c|c|c|}
\hline \multirow[t]{2}{*}{ Forage } & $\overline{\mathrm{DM}(\%)}$ & $-\cdots$ & $\cdots$ & $\% \mathrm{DM}$ & & & $\operatorname{DMD}(\%)$ & DMI $\left(\mathrm{g} / \mathrm{kgW}^{0.75}\right)$ \\
\hline & & $\mathrm{CP}$ & NDF & $A \overline{D F}$ & $A D L$ & Ash & & \\
\hline irec & 29.2 & $\overline{8.22}$ & $\overline{60.35}$ & $\overline{35.59}$ & 3.45 & $\overline{8.22}$ & 48.5 & 40.9 \\
\hline Silage & 26.9 & 8.00 & 64.51 & 40.95 & 4.71 & 9.02 & 46.1 & 36.5 \\
\hline
\end{tabular}

